GRADIATION\&APPLICATIONS

ISSN 2466-4294 (online) | rad-journal.org

Vol. 2 | Issue 3 | pp. $230-232,2017$

doi: 10.21175/RadJ.2017.03.046

Short note

\title{
MOTILITY OF ESCHERICHIA COLI AFTER IRRADIATION WITH GAMMA-RAYS*
}

\author{
Kei Wakimura1, Mikio Kato' ${ }^{1,2^{* *}}$ \\ ${ }^{1}$ Biology Laboratory, Faculty of Liberal Arts and Science, Osaka Prefecture University \\ ${ }^{2}$ Department of Biological Science, Graduate School of Science, Osaka Prefecture University
}

\begin{abstract}
We had previously found that the bacterial flagellar motor is resistant to ionizing radiation at a dose that is sufficient to inhibit bacterial growth. This implies that some enzymatic activity remains after irradiation to maintain the metabolic network in cells. In the present study, to estimate the persistence of bacterial motility after irradiation, we investigated the swimming ability of gamma-irradiated cells after maintenance in a non-nutrient motility medium for several hours at room temperature or at $4^{\circ} \mathrm{C}$. Hence, the motility of the gamma-irradiated cells, which showed no colony-forming ability, lasted for more than 1 day. Swimming speed and the motile fraction were not significantly different between intact (unirradiated) and irradiated cells, whereas these parameters decreased gradually with incubation time. Cells stored at $4{ }^{\circ} \mathrm{C}$ did not swim; however, motility was recovered after bacteria reached room temperature.
\end{abstract}

Key words: Escherichia coli, flagellar motor, gamma rays, ionizing radiation

\section{INTRODUCTION}

Escherichia coli can swim in a liquid medium through the rotation of peritrichous flagella [1]. The flagellar motors of $E$. coli are driven by the electrochemical potential of protons across the cell membrane [2]. This potential is maintained by proton pumps of the electron transport chain, for which the metabolism of organic molecules supplies the electron donors [3].

The effects of ionizing radiation on bacteria have been investigated mostly in the context of food sterilization [4] and mutation rate [5]. Recently, we reported the flagellar motor activity of $E$. coli strain AW405 after the bombardment with an accelerated proton beam [6] and gamma rays [7], and demonstrated its robustness in the presence of a radiation dose that was shown to inhibit the bacterial cell division.

Although bacterial growth ceased because of radiation damage, not all biochemical pathways were obstructed immediately after irradiation. In the present study, we examined the motility of gammairradiated $E$. coli cells over time. After the application of gamma irradiation, the cells retained their ability to swim for several days, even though they stopped proliferating.

\section{MATERIALS AND METHODS}

E. coli strain JM109 was used for all experiments. This strain retains swimming ability in the presence of gamma radiation, similar to strain AW405 [8]. Bacterial cells were cultured in modified T-broth consisting of $0.5 \%(\mathrm{w} / \mathrm{v})$ polypeptone (Nippon Seiyaku, Tokyo, Japan) and $0.5 \%(\mathrm{w} / \mathrm{v}) \mathrm{NaCl}$. Bacterial cells in the logarithmic growth stage were harvested as described previously [7], with minor modifications, and were suspended in motility medium (10 $\mathrm{mM}$ potassium phosphate, $0.1 \mathrm{mM}$ EDTA, and $10 \mathrm{mM}$ sodium lactate) after washing with the same medium. Briefly, cells were cultured in $140 \mathrm{ml}$ of modified T-broth for $3.5 \mathrm{~h}$ at $37^{\circ} \mathrm{C}$ with shaking, and were harvested by centrifugation $(3000 \times g, 6 \mathrm{~min})$. Cells were suspended in $80 \mathrm{ml}$ of the motility medium, centrifuged again, and resuspended in $50 \mathrm{ml}$ of the same medium. The cell suspension was divided into five samples that were subjected to gamma irradiation ( $0.5 \mathrm{kGy}$, $1.0 \mathrm{kGy}$, 2.0 kGy, 4.0 kGy, and no irradiation as a control). The samples were exposed to gamma rays from ${ }^{60} \mathrm{Co}$ in a water pool in Radiation Research Center, Osaka Prefecture University, at room temperature for the period required to administer the designated dose as described previously [7].

Each cell suspension (gamma-irradiated and control samples) was further divided into two samples; one was stored in the refrigerator $\left(4^{\circ} \mathrm{C}\right)$ and the other was incubated in a water bath at $25{ }^{\circ} \mathrm{C}$. At each

\footnotetext{
* The paper was presented at the Fifth International Conference on Radiation and Applications in Various Fields of Research (RAD 2017), Budva, Montenegro, 2017.

mkato@b.s.osakafu-u.ac.jp
} 
K. Wakimura, M. Kato, Motility of Escherichia coli after irradiation..., Rad. Applic., 2017, 2, 3, 230-232

sampling time point, aliquots were diluted at $1 / 10$, and the resultant suspension $(0.3 \mathrm{ml})$ were dropped on a $\varnothing$ $14 \mathrm{~mm}$ glass area with a grid in a ø $35 \mathrm{~mm}$ glass-bottom dish (type D111505 dish, Matsunami Glass, Kishiwada, Japan) and observed under an optical microscope (model CKX31, Olympus, Tokyo, Japan) after samples reached ambient temperature. Bacterial motility was recorded as a movie file $(29.97 \mathrm{fps}, 640 \times 480$ pixels $)$ using a digital camera (model EX-P505, Casio, Tokyo, Japan). After the movie files (mpeg4 format) were converted to uncompressed AVI files, they were analyzed by ImageJ software (internet URL, https://imagej.nih.gov/ij/).

The number of bacterial cells in each field of view was counted, and cell motility was examined. The subject plane of the camera was set close to the glass substrate (bottom of the dish), and cells that were out of focus were not considered. The observed cells were categorized into three groups: no motility (remained on the substrate or drifting), unusual motility (rolling or tethered to the substrate via single flagellum to rotate), and smooth swimming cells. Swimming speed was estimated on the basis of the distance travelled by smooth swimming cells over 16 consecutive frames (corresponding to 15 frame-intervals equaling $0.5 \mathrm{sec}$ each).

\section{RESULTS AND DISCUSSION}

After gamma-irradiation, turbidity and viability of samples were estimated. The samples showed OD6oo scores (absorbance at $600 \mathrm{~nm}$ ) of 0.233 (no irradiation control), 0.234 (0.5 kGy), 0.241 (1.0 kGy), 0.239
(2.0 kGy), and 0.230 (4.0 kGy), respectively. There were $1.4 \times 10^{8}$ colony-forming units per milliliter $(\mathrm{CFU} / \mathrm{ml})$ in the control sample. No CFUs were detected in any of the irradiated samples, indicating that gamma irradiation with $0.5 \mathrm{kGy}$ resulted in a $>10^{8}$-fold reduction in bacterial colony-forming ability. For each sample, movies from three to eight distinct fields were recorded, depending upon the density of visible cells. The cell density for each sample is shown in Table 1. The motile fraction decreased gradually during storage (Figure 1). Cells at $4{ }^{\circ} \mathrm{C}$ (just after removal from the refrigerator) did not show swimming ability, but regained motility after reaching ambient temperature. Swimming speed was estimated using the trace lengths of smooth swimming cells (Table 2).

The trends for time-dependent decreases in the motile fraction and swimming speed were more prominent in the samples stored at $25{ }^{\circ} \mathrm{C}$. This might mean that the energy sources required for motility were consumed by the cells during storage at $25{ }^{\circ} \mathrm{C}$, but not at $4{ }^{\circ} \mathrm{C}$. The present results suggest that physiological activity in non-dividing cells remains for more than 1 day, and that the active state can be sustained for a longer period by storing the cells at $4{ }^{\circ} \mathrm{C}$.

Since motility is maintained by the cooperation of several enzymes and machinery, one can expect that a certain level of other physiological activities, e.g., gene expression [9], may remain in the gamma-irradiated cells. In that regard, the non-dividing but motile cells might be applicable for developing a novel vehicle of chemical and biological materials, like bacterial minicells [10].

Table 1. Observed cell density in microscopic fields (number of cells per $0.01 \mathrm{~mm}^{2}$ )

\begin{tabular}{ccccccccc}
\hline & \multicolumn{3}{c}{ Stored at $25^{\circ} \mathrm{C}$} & \multicolumn{5}{c}{ Stored at $4{ }^{\circ} \mathrm{C}$} \\
\cline { 2 - 9 } Dose applied & \multicolumn{7}{c}{ Time after irradiation (h) } \\
\hline Control & 0 & 25 & 48 & 72 & 25 & 48 & 72 \\
\hline 0.5 kGy & 46.2 & 12.3 & 6.4 & 3.1 & 36.9 & 54.9 & 43.0 \\
$1.0 \mathrm{kGy}$ & 42.4 & 19.1 & 8.2 & 15.3 & 46.9 & 50.7 & 36.3 \\
$2.0 \mathrm{kGy}$ & 53.7 & 18.0 & 14.9 & 8.5 & 58.7 & 38.6 & 36.4 \\
$4.0 \mathrm{kGy}$ & 53.3 & 12.8 & 7.4 & 2.5 & 49.1 & 49.2 & 28.9 \\
\hline
\end{tabular}
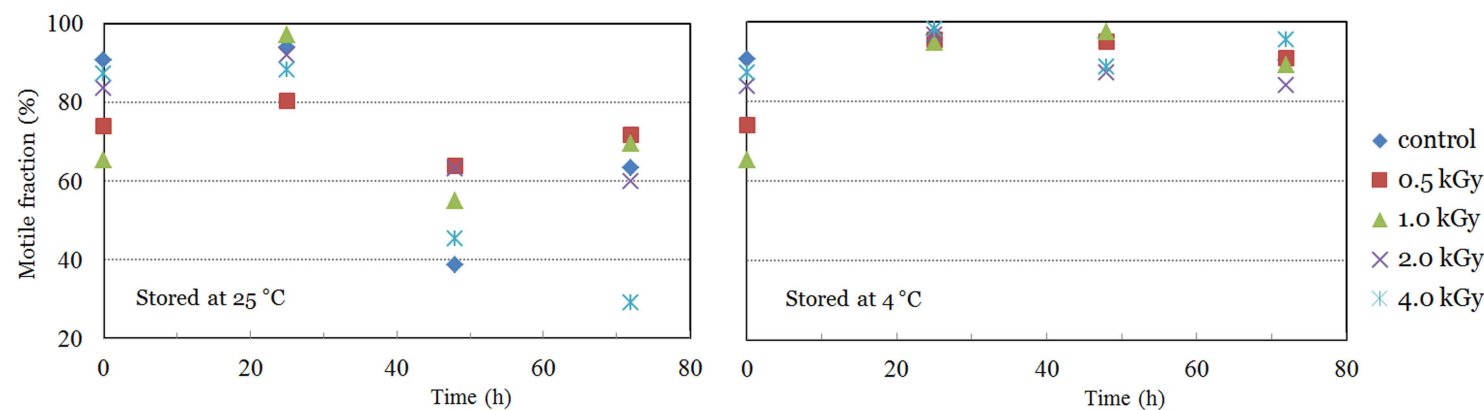

Figure 1. Motile fraction (\%) after irradiation.

The motile fraction was calculated by dividing the sum of moving cells (unusual motility and smooth swimming) by the total number of cells in the field. 
K. Wakimura, M. Kato, Motility of Escherichia coli after irradiation..., Rad. Applic., 2017, 2, 3, 230-232

Table 2. Average speed of smooth swimming cells

Speed is reported in $\mu \mathrm{m} / \mathrm{sec}$ and standard deviation is shown in parentheses.

\begin{tabular}{cccccccc}
\hline & \multicolumn{3}{c}{ Stored at $25{ }^{\circ} \mathrm{C}$} \\
\cline { 2 - 8 } Dose applied & 0 & 25 & 48 & 72 & 25 & 48 & 72 \\
\hline Control & $12.80(6.78)$ & $8.82(4.89)$ & $7.84(5.59)$ & $6.84(4.08)$ & $11.64(4.77)$ & $13.26(5.22)$ & $12.63(4.67)$ \\
$0.5 \mathrm{kGy}$ & $18.97(6.78)$ & $9.64(5.64)$ & $9.96(5.65)$ & $7.78(4.29)$ & $12.86(5.19)$ & $10.64(5.11)$ & $11.58(4.64)$ \\
$1.0 \mathrm{kGy}$ & $15.03(6.73)$ & $10.93(5.67)$ & $9.13(5.01)$ & $8.24(4.86)$ & $11.72(5.41)$ & $11.06(5.23)$ & $11.15(4.89)$ \\
$2.0 \mathrm{kGy}$ & $13.23(6.20)$ & $10.43(5.91)$ & $8.96(6.18)$ & $8.67(5.01)$ & $11.41(5.28)$ & $11.97(5.93)$ & $11.10(5.59)$ \\
$4.0 \mathrm{kGy}$ & $11.55(5.27)$ & $8.22(4.73)$ & $6.12(4.25)$ & $5.27(4.92)$ & $10.14(3.76)$ & $11.04(5.12)$ & $11.93(4.81)$ \\
\hline
\end{tabular}

\section{CONCLUSIONS}

Motility of non-dividing bacterial cells that were prepared by gamma-irradiation lasted for more than 1 day. A shelf life of motile cells will be prolonged by being stored at $4{ }^{\circ} \mathrm{C}$.

Acknowledgement: The authors would like to thank the staff of the Radiation Research Center of Osaka Prefecture University for kind support in the gamma irradiation experiments.

\section{REFERENCES}

1. H. C. Berg and R.A. Anderson, "Bacteria swim by rotating their flagellar filaments," Nature, vol. 245, no. 5425. pp. $380-382$, Oct. 1973 .

DOI: $10.1038 / 245380 a 0$ PMid: 4593496

2. H.C. Berg, "The rotary motor of bacterial flagella," Ann. Rev. Biochem., vol. 72, pp. 19 - 54, Jul. 2003. DOI: 10.1146/annurev.biochem.72.121801.161737 PMid: 12500982

3. B. Alberts et al., "Electron-transport chains and their proton pumps," in Molecular Biology of the Cell, 4th ed., New York (NY), USA: Garland Science, 2002, ch. 14, sec. 2.

Retrieved from: https://www.ncbi.nlm.nih.gov/books/NBK26904/ Retrieved on: Jan. 26, 2017

4. M. W. Schilling et al., "Effects of ionizing radiation and hydrostatic pressure on Escherichia coli $\mathrm{O} 157: \mathrm{H} 7$ inactivation, chemical composition, and sensory acceptability of ground beef patties," Meat Sci., vol. 81, no. 4, pp. $705-710$, Apr. 2009.

DOI: $10.1016 /$ j.meatsci.2008.10.023 PMid: 20416567

5. J. Cadet, T. Douki, D. Gasparutto, J.-L. Ravanat, "Radiation-induced damage to cellular DNA: measurement and biological role," Radiat. Phys. Chem., vol. 72, no. 2-3, pp. 293-299, 2005.

DOI: $10.1016 /$ j.radphyschem.2003.12.059

6. M. Kato, W. Meissl, K. Umezawa, T. Ikeda and Y. Yamazaki, "Real-time observation of Escherichia coli cells under irradiation with a $2-\mathrm{MeV} \mathrm{H}^{+}$microbeam," Appl. Phys. Lett., vol. 100, 193702, May 2012. DOI: $10.1063 / 1.4714911$

7. T. Atsumi, E. Fujimoto, M. Furuta and M. Kato, "Effect of gamma-ray irradiation on Escherichia coli motility," Cent. Eur. J. Biol., vol. 9, no. 10, pp. 909 - 914, Oct. 2014.

DOI: 10.2478/s11535-014-0332-Z

8. M. Kato, "Effect of ionizing radiation on the motility of Escherichia coli," in Microbes in the Spotlight: Recent Progress in the Understanding of Beneficial and Harmful Microorganisms, A. Méndez-Vilas, Ed., Boca Raton (FL), USA: BrownWalker Press, 2016, pp. 478 482.

9. M. Kato and A. Futenma, "Expression of the lac $Z$ gene in Escherichia coli irradiated with gamma rays," J. Radiat. Res. Appl. Sci., vol. 7, no. 4, pp. 568 - 571, Oct. 2014.

DOI: 10.1016/j.jrras.2014.09.008

10. M. J. Giacalone et al., "The use of bacterial minicells to transfer plasmid DNA to eukaryotic cells," Cell. Microb. vol. 8, no. 10, pp. 1624 - 1633, Oct. 2006.

DOI: 10.1111/j.1462-5822.2006.00737.x

PMid: 16984417 